\section{An overview of mercury contamination research in the Amazon basin with an emphasis on Brazil}

\author{
Uma revisão das pesquisas sobre contaminação \\ por mercúrio na Amazônia com ênfase \\ no território brasileiro
}

\author{
${ }^{1}$ Escola Nacional de Saúde \\ Público Sergio Arouca, \\ Fundação Oswaldo Cruz, \\ Rio de Janeiro, Brasil. \\ 2 Instituto de Comunicação \\ e Informação Científica \\ e Tecnológica em Saúde, \\ Fundação Oswaldo Cruz, \\ Rio de Janeiro, Brasil. \\ 3 Instituto de Geociências, \\ Universidade Federal \\ Fluminense, Rio de Janeiro, \\ Brasil. \\ 4 Departamento de Química, \\ Pontificia Universidade \\ Católica do Rio de Janeiro, \\ Rio de Janeiro, Brasil. \\ Correspondência \\ S. Hacon \\ Departamento de Endemias \\ Samuel Pessoa, Escola \\ Nacional de Saúde Pública \\ Sergio Arouca, Fundação \\ Oswaldo Cruz. \\ Rua Leopoldo Bulhões 1480 \\ Rio de Janeiro, $R J$ \\ 21041-210, Brasil. \\ shacon@easyline.com.br
}

\begin{abstract}
This article provides an overview of research on mercury contamination in the Amazon Basin and its evolution from 1990 to 2005. The assessment was based on an extensive and systematic review using bibliographic databases available online and a review of projects by research groups. Brazilian research groups were identified using the database of the Brazilian National Research Council (CNPq). A geographic information system was used to determine the location of the studies. Different aspects of mercury contamination were evaluated (environmental studies, impacts on human health, technological improvements). For 1990-2005, a total of 455 publications were identified. The main advances and remaining gaps in relation to environmental issues and human health were identified and discussed. Although the scientific output varied considerably over the period, there was a general increase in the total number of publications per year from the early 1990s (fewer than 20) until 2005 (more than 30), considering the articles published in indexed journals.
\end{abstract}

Mercury Poisoning; Environmental Pollution; Mercury; Amazonian Ecosystem
Sandra Hacon 1

Paulo R. G. Barrocas 1

Ana Claudia S. de Vasconcellos 1

Christovam Barcellos 2

Julio César Wasserman 3

Reinaldo C. Campos 4

Cíntia Ribeiro ${ }^{1}$

Flávia B. Azevedo-Carloni ${ }^{3}$

\section{Introduction}

Gold mining increased markedly in many developing countries in the last quarter of the $20^{\text {th }}$ century, following fluctuations in gold prices on the world market. In almost all the countries in the Amazon basin, mercury (Hg) was used in the gold extraction process. Concerns regarding mercury contamination in the Amazon Basin were first raised in the early 1980s, when studies emphasized that significant amounts of the metal were being dumped into the Amazonian ecosystem as a result of this "gold rush" 1,2,3,4,5,6,7,8,9.

Studies have shown that the metallic mercury released in aquatic systems or into the atmosphere can be oxidized to $\mathrm{Hg}^{2+}$ and later converted to methylmercury by various mechanisms, mostly bacteria-mediated reactions 10 . Fat solubility of mercury compounds means that higher predators present the greatest $\mathrm{Hg}$ levels, due to biomagnification along the food chain 11,12,13 Consumption of aquatic organisms contaminated with mercury is the main exposure route for humans 14,15,16.

High mercury levels were found in the Brazilian Amazon ecosystems, attributed initially to gold mining activities only 17,18,19,20,21. However, some authors later suggested that Amazonian soils have high natural mercury concentrations that could explain the $\mathrm{Hg}$ levels measured in fish and humans in the region 22,23,24. Other authors hypothesized that atmospheric transport 
of anthropogenic mercury might account for the widespread contamination of the Amazon basin $25,26,27,28$. In addition, deforestation for cattle-raising and agriculture occurred at high rates since the early 1970s, increasing the soil erosion and probably contributing directly (and indirectly) to mercury dispersion. Moreover, large reservoirs formed for hydroelectric power generation in the Brazilian Amazon favored mercury mobilization and methylmercury production 29,30 . Whatever the main source of mercury emission in the Amazon basin, these studies suggested a large variation in background mercury concentrations and/ or a large-scale transport of mercury throughout the region.

Despite the good available documentation on contamination of the biota, sediments, soils, and some local populations (especially riparian communities) in the Amazon, mercury sources and sinks in the Brazilian Amazon are not well established, and a full understanding of the metal's biogeochemical cycle is still not available. Some Amazonian riverine populations have high hair mercury levels, attributed to a diet based on fish, the main source of protein $31,32,33,34,35,36,37,38,39,40$. Current international efforts (UNIDO, IBRD, USEPA) to lower mercury emissions or replace mercury with harmless substances are expected to reduce methylmercury accumulation in aquatic ecosystems. However, given the amount of mercury already present in the Amazon ecosystem and its persistency, this approach must be viewed as a long-term mitigation plan.

Mercury has been recognized as a significant public health problem for more than 40 years, due mainly to its effects on the developing nervous system, as expressed in the tragic cases of human poisoning in Japan and Iraq. The effects included mental retardation, cerebral palsy, deafness, blindness, and dysarthria in individuals who were exposed in uterus, and sensory and motor impairment in exposed adults. Chronic low-dose prenatal methylmercury exposure from maternal consumption of fish has been associated with more subtle endpoints of neurotoxicity in children $41,42,43,44,45,46$. There is also evidence in humans and animals that exposure to methylmercury can lead to adverse effects on the developing and adult cardiovascular system 47,48.

Many researchers have observed that there is no noticeable acute sign of contamination in humans in the Amazon basin. However, a few researchers have analyzed the neurological effects of low mercury exposure. Lebel et al. 49 applied neurobehavioral tests to a group of residents along the Tapajós River whose sole source of mercury was through consumption of contaminated food. The authors suggest a risk of neurological disorders, and that some neurotoxic alterations of motor functions can be detected even below the threshold value of 50ppm in hair set by the World Health Organization ${ }^{46}$. However, the effects on humans, especially neurotoxicity in traditional populations, remain to be understood, as do the ecological impacts of methylmercury on Amazonian wildlife.

This paper presents a literature review on mercury contamination in the Amazon Basin and its evolution over time. The assessment is based on an extensive and systematic review of research projects and scientific data produced from 1990 to 2005. It includes dissertations, theses, articles, reports, and books. Various aspects (e.g. environmental surveys, impacts on human health, technological improvements, etc.) were surveyed and analyzed. The evolution in approaches used in the studies was also reviewed. The main achievements and remaining gaps in knowledge on environmental issues and health impacts on humans were identified and discussed.

\section{Methodology}

A systematic and extensive review of electronic databases was performed using specific key words to identify studies on mercury contamination in the Amazon basin, from 1990 to 2005. Researchers and research groups involved in this issue were also identified and organized as a function of different aspects of their work, including topics, methodologies, and geographic location. Searches were conducted in Spanish, English, and Portuguese in the following bibliographic databases available on the Internet: (1) PubMed (http://www.ncbi.nlm.nih.gov/entrez/query. fcgi); (2) U.S. National Library of Medicine Gateway (http://gateway.nlm.nih.gov/gw/Cmd); (3) MEDLINE (http://medlineplus.gov); (4) Web of Science database from the ISI Web of Knowledge website (http://go5.isiknowlwdge.com/portal. cgi/); (5) LILACS - Latin America and Caribbean Health Sciences (http://bases.bireme.br/cgibin/wxislind.exe/iah/online/? IsisScript=iah. is7base=LILACS\&lang=p); and (6) Periódicos CAPES website (http://www.periodicos.capes. gov.br).

The collected data were filtered and organized to answer four main questions: (1) Who has been conducting research on mercury contamination in the Amazon basin? (2) Where have the studies been conducted? (3) In which journals have the results been published? and (4) What types of studies have been performed?

A geographic information system (GIS) was used to answer question 2. If geographic coor- 
dinates were available, they were recorded; otherwise, a complex geocoding strategy was carried out to recover the locations mentioned. We verified the correct position of these sites by pinpointing them on a digital map, which contained reference layers such as rivers, cities, villages, indigenous communities and reserves, and municipal (or county) limits. If the description of the research site differed from that verified, a second strategy was applied, consisting of retrieving maps published in the selected articles. The maps allowed recognizing topographic references like rivers, lakes, and villages and pinpointing the site on the reference map. A third strategy consisted of collecting place names cited as the research sites and identifying their coordinates using databases like the list of municipalities (counties) and villages in Brazil (Instituto Brasileiro de Geografia e Estatística; http://www.ibge.gov.br) and Internet location gazetteers (Multimap - http:// www.multimap.com; Maplandia - http://www. maplandia.com). Finally, the fourth strategy identified the names of rivers and lakes cited in the paper on the reference digital map. Since rivers are often used as the main form of access to fieldwork in the Amazon and also represent the main transportation and cycling pathway for mercury, these waterways are frequently cited in the publications. Since all these spatial units have large dimensions in the Amazon (e.g. rivers more than $1,000 \mathrm{~km}$ long and municipalities larger than $100,000 \mathrm{~km}^{2}$ ), a combination of strategies employed, for example, by searching for the confluence of rivers or a site on river $A 120 \mathrm{~km}$ downstream from city $B$. Using this procedure, the positioning error of some sites is estimated at $30 \mathrm{~km}$, which is compatible with the original scale of the reference map $(1: 10,000,000)$.

In order to establish the profile of the research groups and individual researchers working in the Amazon, specific Brazilian databases like the Brazilian Directory of Research Groups of the National Research Council (CNPq; http:// lattes.cnpq.br) and PROSSIGA from the Ministry of Science and Technology (http://prossiga.ibict. br) were also analyzed.

The CNPq censuses of research groups were started in 1992 and now include most active Brazilian researchers 50 . These databases list the researchers, staff, and students in each group, their respective research subjects, and the main scientific area. Key words were used to identify research groups in different fields (e.g. name of group, name of research topic, title of publications, etc.). Some groups may not appear because they perform research on mercury contamination in the Amazon but not exclusively in this region and they did not use "Amazon" as a key word in their research results (rather, for example, mercury and "tropical ecosystems"). While admitting the possible limitations of this approach, the methodology was applied to each CNPq census (1993, 1995, 1997, 2000, 2002, and 2005).

In addition, Brazilian Federal and State research funding agency databases were examined to identify the funding allocated to the study of mercury contamination in the Amazon. The amount of funding allocated to each subject (grants and/or fellowships) allowed the evaluation of the relevance ascribed to the issue by the Brazilian government. The PROSSIGA database from $\mathrm{CNPq}$ allows searches for scholarships (e.g. technical support, productivity, visiting professor) and research projects (individual and institutional) using key words. The data included the Federal (CAPES, CNPq, and FINEP) and some Statefunding agencies, namely from Pernambuco (FACEPE), Minas Gerais (FAPEMIG) Rio Grande do Sul (FAPERGS), Rio de Janeiro (FAPERJ), São Paulo (FAPESP), and Ceará (FUNCAP) that are responsible for the main financial support for scientific research in Brazil.

Besides Brazilian research groups, these databases also allowed identifying cooperation with foreign groups. Although groups from other Amazonian countries are involved in mercury research, organized databases could not be identified and these researchers could not be included in this paper.

The documents analyzed in this review were mostly articles from scientific journals that are indexed in international or national databases. There are two main reasons: first, articles are considered the most important and most efficient way of disseminating scientific knowledge. Scientific journals are published much more quickly than books and reports, so their data tend to be the most up-to-date available. In addition, scientific journals usually use peer reviewing, the main mechanism for assuring quality of information. Abstracts and other documents with less than two pages, as well as documents with unidentified authors or institutions, were not included.

Most of the data were collected from electronic sources. Access to the full text was fundamental in order to depict parameters like type of study, matrices, etc. However, for specific analyses (e.g. number of publications per year) the relevant books, reports, and theses or dissertations were also included, although some were difficult to access.

The set of information collected in the texts was carefully organized in a spreadsheet, allowing a complete set of statistical analyses. 


\section{Results and discussion}

From 1990 to 2005, a total of 455 publications on mercury contamination in the Amazon Basin were identified, including 42 theses and dissertations, 28 reports, 19 books, 323 articles published in scientific journals, and 43 extended abstracts presented at scientific meetings (Figure 1). Although the production varied considerably over the period, there was a general increase in the total number of publications per year from the early 1990s (fewer than 20/year) to the end of the period (more than 30 ), which is expressed most clearly by the articles published in indexed journals. There was a peak in the year 2000 (50 references), and a slight decrease in the last two years (25 and 27, respectively).

Concerning question 1 , few research institutions were working with mercury contamination in the Amazon in the early 1980s. Important international cooperation only began in the following decade. Figure 2 shows the predominance of Brazilian research groups as compared to those from other Amazon basin countries: 166 Brazilian articles, followed by Colombia (5), Bolivia (4), Suriname (3), and Ecuador (2). The remaining countries produced only one publication during this period. The presence of research groups from different Amazonian countries began in 1997 and slowly increased in the later years of the period analyzed.

Brazilian research institutions produced the most publications based on international cooperation between countries from the Amazon basin. Although the number of Brazilian institutions studying mercury contamination in the Amazon remained stable during the period (23 in 19901997 and 25 in 1998-2005), the number of international institutions cooperating with Brazilian researchers increased in the last eight years (27 institutions) as compared to the early 1990s (13). Concerning cooperation between international research institutions and Brazilian researchers in the early part of the period (1990-1997), the main partners were Japanese (43\%), American (24\%), and Canadian (14\%) institutions. However, in the latter part of the period (1998-2005) Canadian research institutions became the main Brazilian partners (30\%), followed by American (19\%), Japanese (11\%), and Swedish (11\%) institutions. International institutions began collaborating with other countries in the Amazon Basin in 1998. For example, 3 research institutions from Suriname cooperated with 2 Dutch institutions and 2 from Ecuador cooperated with 3 American and 1 Swedish institution.

A consistent way of analyzing the evolution of mercury research in the Amazon is to examine the research groups involved in it, as opposed to individual researchers. This unit of analysis implies that there is a research topic that is shared by a number of researchers with common research objectives and projects. We used the CNPq censuses for this analysis, searching for "Amazon" and "mercury" as key words. This criterion only identifies groups that have these words in their main research activities/interests. This approach may have excluded some traditional research groups that conduct studies on mercury contamination in the Amazon but not exclusively in this region or that did not use these key words in the searched field. Thus, the possible limitation of these secondary data should always be kept in mind. Table 1 shows more detailed information on research groups currently listed in the $\mathrm{CNPq}$ database. This census contains the information surveyed until July 15, 2002, as well as updates made by principal investigators until April 2005. The total number of research groups was stable (around 8 groups) after a peak in the late 1990s (13 groups). However, since Figure 3 shows whether the origin of the research groups is considered (whether they belong to institutions located in the Amazon basin), there is an evident shift in the predominance of the research groups: from 2000 on, research groups from Amazonian institutions were consolidated and became the majority.

Brazilian and international partnerships contributed to the development of the Amazonian institutions' research groups, as illustrated by the cooperation between the Radioisotopes Group from the Federal University in Rio de Janeiro and the Environmental Biogeochemistry Group of the Federal University in Rondônia. Another outstanding case involves the research group on Mercury Contamination in Human Populations and the Amazonian Environment at the Evandro Chagas Institute, working with the Department of Environmental Medicine of Odense University, Denmark, but also interacting with other Brazilian research groups such as the Federal University in Pará through its Mineral Technology Center (CETEM) and the Collective Health Nucleus of the Federal University in Rio de Janeiro (NESC/UFRJ).

Two research groups stand out in Table 1 (the Federal University in Rondônia - UNIR, and the Catholic University in Campinas - PUC-Campinas, São Paulo State) in relation to the number of researchers, students, and staff. Each has more than 10 students involved in research subjects related to mercury contamination in the Amazon. The group from São Paulo State focuses mainly on analytical development, while that from Rondônia is primarily concerned with environmental assessment. 
Figure 1

Number and type of publications per year, 1990 to $2005(n=455)$.

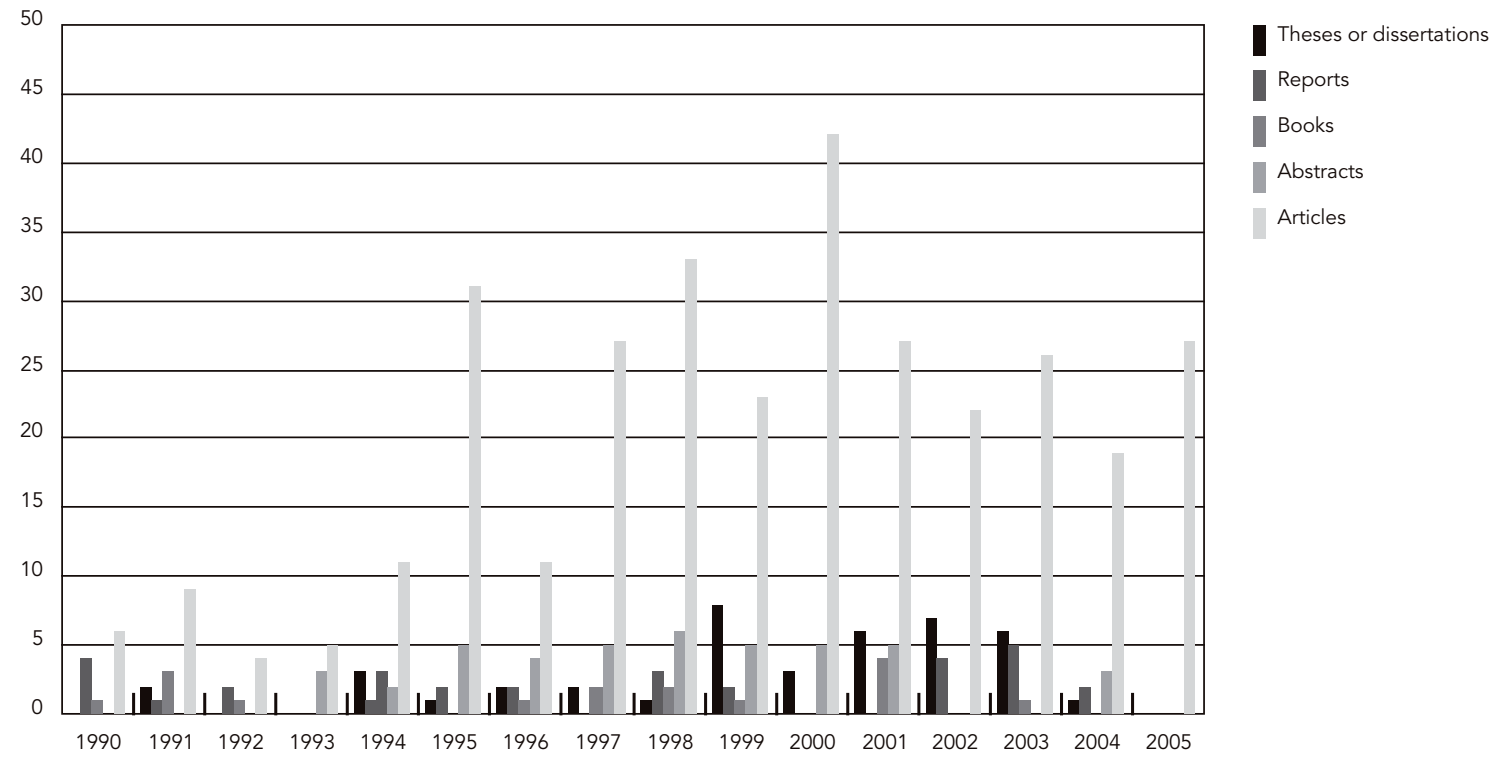

Figure 2

Scientific articles published by research institutions in the Amazon basin countries, 1990 to $2005(n=182)$

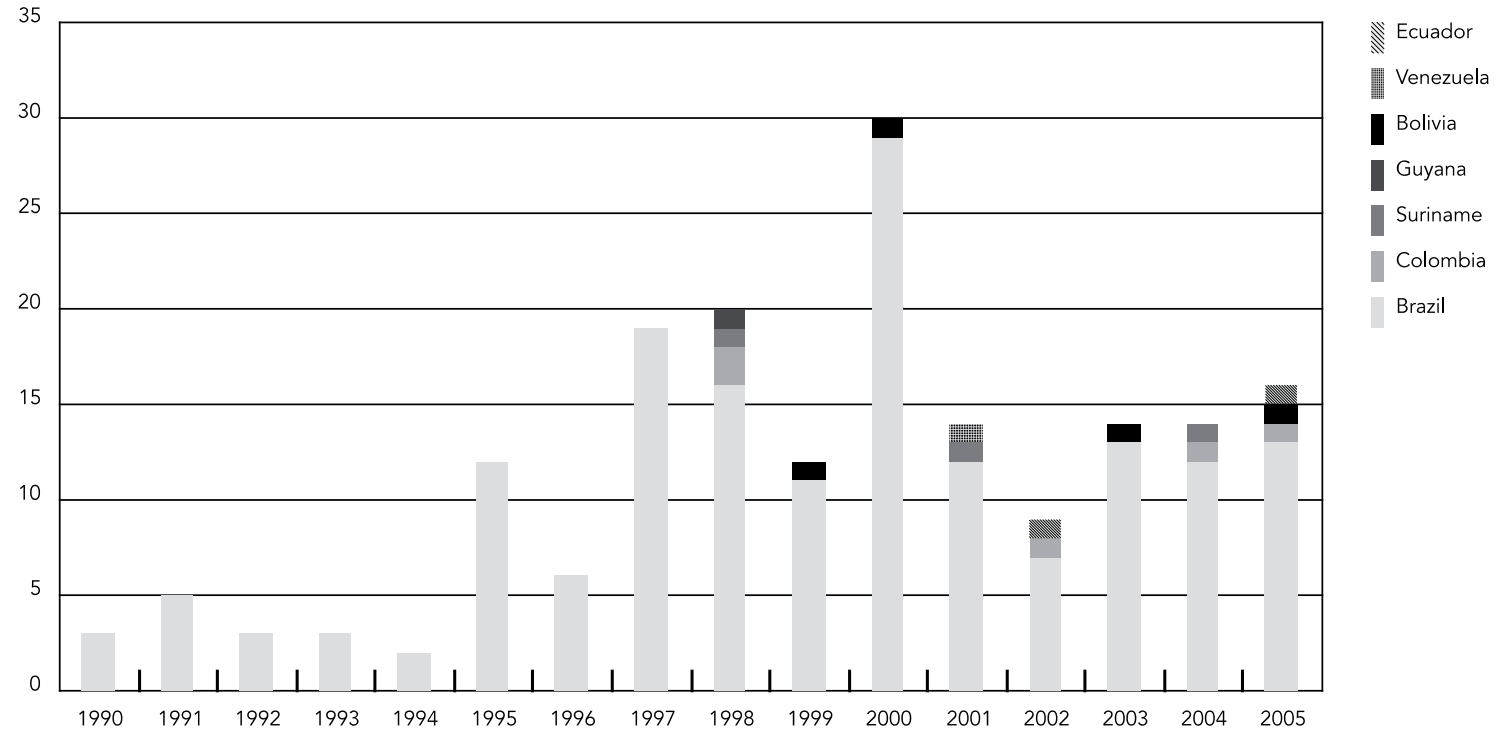


Research groups currently listed in CNPq database where "mercury" and "Amazon" appear in the research group's name or as research subject name or key words.

\begin{tabular}{|c|c|c|c|}
\hline Research groups & Brazilian institutions & Research subject & Area \\
\hline $\begin{array}{l}\text { Mineralogy and Applied } \\
\text { Geochemistry }\end{array}$ & Federal University in Pará & $\begin{array}{c}\text { Characterization and application of mining } \\
\text { residues }\end{array}$ & Geoscience \\
\hline Toxicology & Federal University in Pará & $\begin{array}{c}\text { Total mercury determination in biological } \\
\text { and environmental samples }\end{array}$ & Pharmacology \\
\hline $\begin{array}{l}\text { Mercury in Amazonian } \\
\text { Populations and the } \\
\text { Environment }\end{array}$ & Evandro Chagas Institute & Amazonian populations exposed to mercury & Public Health \\
\hline $\begin{array}{l}\text { Environmental Biogeochemistry } \\
\text { Laboratory }\end{array}$ & Federal University in Rondônia & $\begin{array}{c}\text { Assessment of environmental and human } \\
\text { contamination by mercury in the Maderia } \\
\text { River basin }\end{array}$ & Geoscience \\
\hline Coastal Biogeochemistry & Federal University in Ceará & Mercury biogeochemistry in tropical areas & Ecology \\
\hline $\begin{array}{l}\text { Environmental Analytical } \\
\text { Chemistry }\end{array}$ & University of Brasilia & $\begin{array}{c}\text { Analytical and toxicological aspects of } \\
\text { mercury }\end{array}$ & Chemistry \\
\hline Environmental Chemistry & Catholic University of Campinas & Environmental chemistry & Chemistry \\
\hline Radioisotopes Laboratory & $\begin{array}{c}\text { Federal University in Rio de } \\
\text { Janeiro }\end{array}$ & $\begin{array}{l}\text { Environmental, health, and ecotoxicological } \\
\text { aspects of environmental pollution by heavy } \\
\text { metals and organic substances, especially } \\
\text { mercury, in gold mining areas of the Amazon }\end{array}$ & Ecology \\
\hline
\end{tabular}

CNPq: Brazilian National Research Council.

The impact of funding for mercury contamination research in the Amazon was not possible, since this information was not available in the databases. There was also an evident need for an integrated common database for Amazon Basin countries to effectively share scientific information.

Another way to assess the current and future development in a research area is to examine the related scholarships and research project grants. The database results showed two CNPq grants at UFRJ and the State University in Campinas (UNICAMP). The database also identified six Ph.D. scholarships at the Federal University in Minas Gerais (UFMG), the National Institute for Research in the Amazonia (INPA), UNICAMP, and Sao Paulo State University (UNESP), one post-doctoral fellowship at the Nuclear Energy Research Institute (IPEN), and two junior fellowships at the Federal University in Pará (UFPA) and INPA. These results indicate that the funds allocated to mercury research in the Amazon were limited, considering the importance and extent of the mercury problem. Nevertheless, the present survey could not exhaustively identify records of projects in the most important funding agencies. This appears to be a major flaw in the management of research funds, hindering efficient planning of future investments

Evaluation of the CNPq censuses suggests that mercury contamination in the Amazon is a well-established research topic among Brazilian research institutions, including those with headquarters in the Amazon region itself, where research groups are actively producing scientific data on the subject.

Concerning question 2, Figure 4 shows that the main sampling sites are located along the Madeira and Tapajós Rivers in Brazil, the Madalena River in Colombia, and small rivers and lakes in French Guiana and Suriname. The Brazilian Amazon (128 sampling sites) is the most extensively studied area, followed by Suriname (7 sampling sites), and French Guyana (6 sampling sites), while Peru and Venezuela show limited 
Trend in the number and predominance of Brazilian research groups studying mercury in the Brazilian Amazon region, according to CNPq censuses.

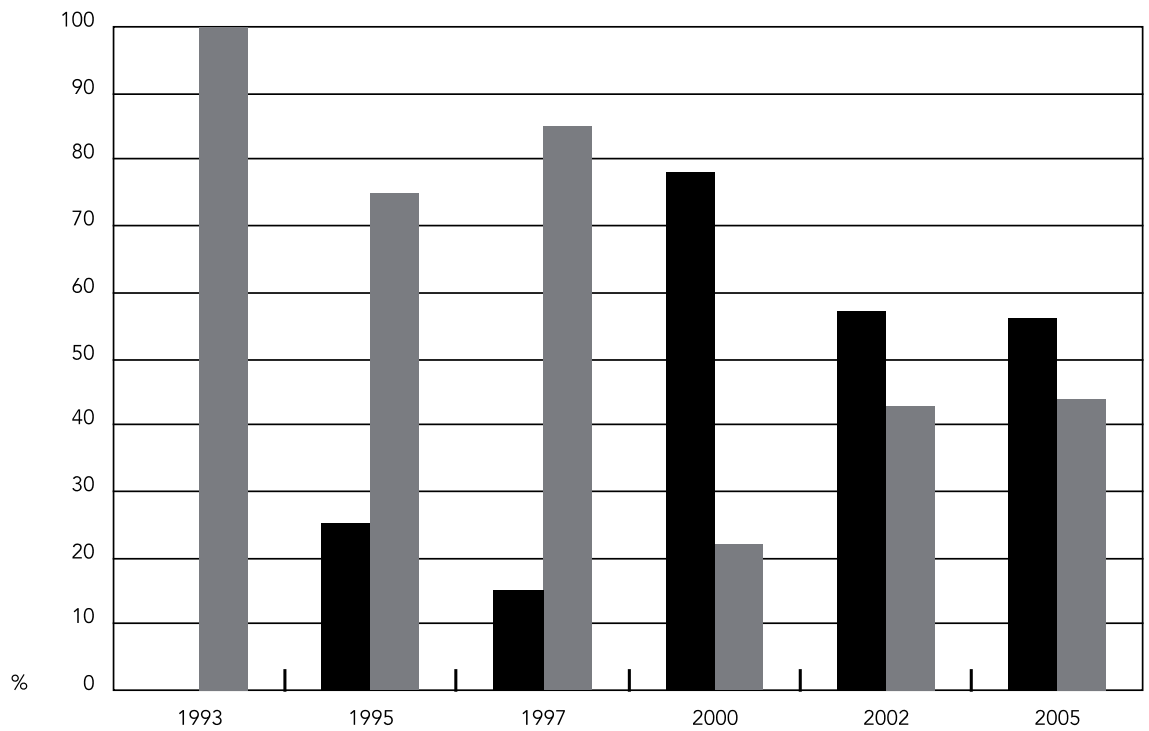

CNPq: Brazilian National Research Council.

mercury research in their Amazonian territories (2 sampling sites). The map also indicates that research is insufficient in large rivers flowing from the Andes (Putamayo, Solimões, Marañon). The Beni River in Bolivia is the only exception, with a dense network of research sites. Other rivers such as the Negro and Purus are scarcely studied.

This spatial distribution reflects the location of alluvial gold-mining camps (garimpos) and large-scale mining activities in the Amazon basin. For instance, along the Tapajós River, intensive alluvial mining has been taking place since the 1950s. During the 1990s, mining activity covered more than $150,000 \mathrm{~km}^{2}$, with 60,000 alluvial miners or garimpeiros 51. Alta Floresta (Teles Pires River), Serra do Navio (Tartarugalzinho and Amapari Rivers), and Porto Velho (Madeira River) were also important garimpo areas 52 . The most extensively studied basins (Tapajós, Madeira, and Tocantins) are also the most heavily impacted by gold mining 53,54,55.

This spatial pattern changed significantly in the last decade. Research tended to spread from Brazil to other countries and territories such as French Guiana, Suriname, Peru, Ecuador, and Bolivia. This dispersion also occurred from the garimpos to remote areas. The shift probably reflects the hypothesis that mercury sources in the Amazon are naturally enriched soils rather than gold mining 17 . In addition, gold mining declined considerably over the last decade. The recent spatial distribution of studies in the Amazon is more scattered and upstream relative to the impacted mining areas. Examples of this shift are the Beni and Negro Rivers. Maurice-Bourgoin et al. 56 and Santos et al. 57 justify their study location as a search for natural background mercury in areas not impacted by gold mining.

In relation to question 3 , mercury contamination studies in the Amazon have generated publications in various scientific journals. The top five scientific journals, considering the number of articles published on different aspects of this research topic, were The Science of the Total Environment (36 articles), Environmental Research (30 articles), Water, Air and Soil Pollution (25 articles), Ambio (14 articles), and Cadernos de Saúde Pública (9 articles). While most of these journals have environmental scientists as their main readers, Cadernos de Saúde Pública is mainly devoted to health-related articles. These are the two main approaches of studies on mercury contamination in the Amazon basin.

Both international and Amazonian research groups chose indexed international journals to publish their results. These choices were based on several issues such as time-to-publication, journal impact, popularity within the scientific 


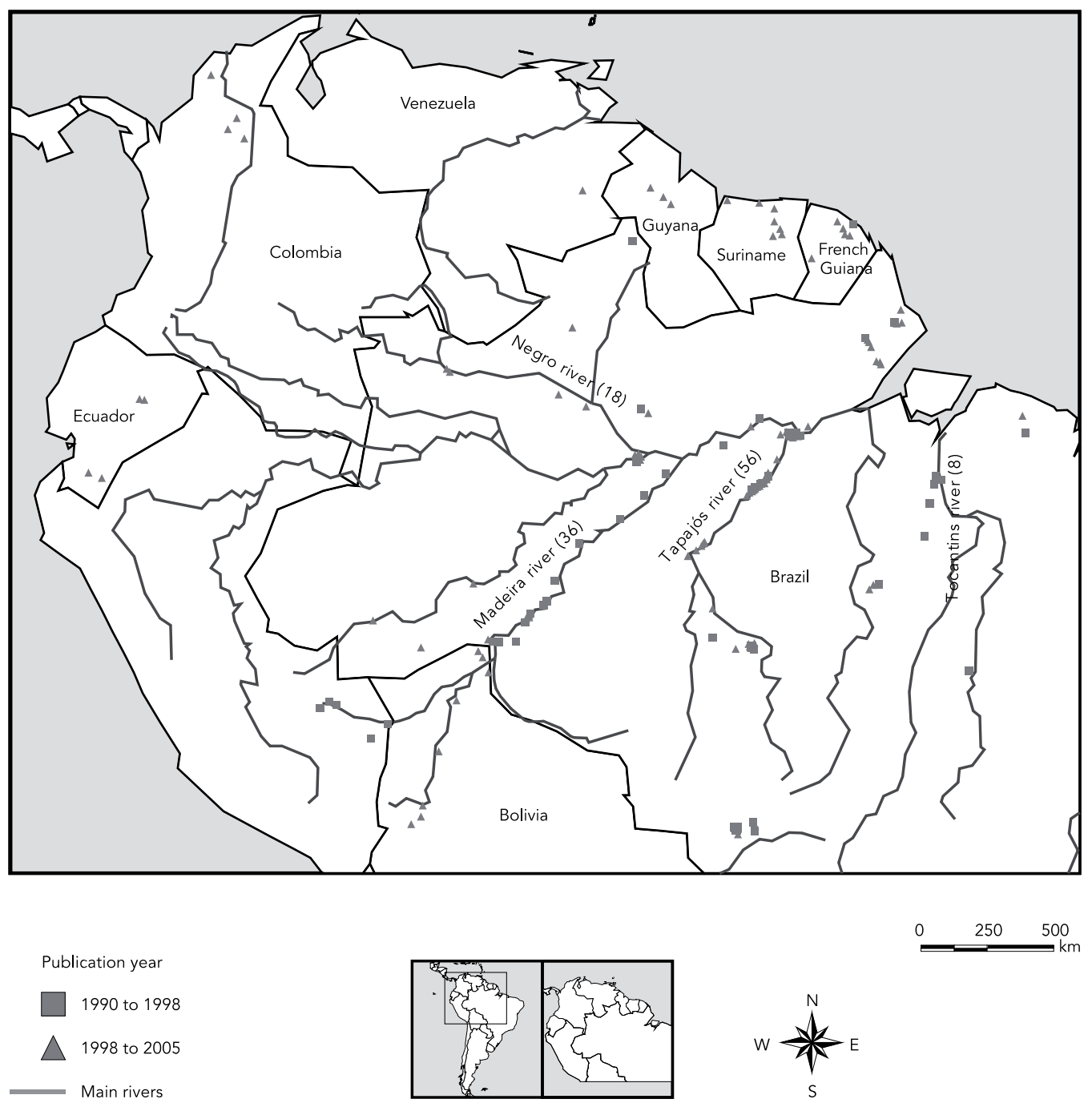

community, and accessibility to articles. This last topic has received growing attention due to the possibilities offered by online electronic journals, including a few initiatives involving open-access scientific journals.

Although publishers of scientific journals immediately recognized the advantages of creating electronic versions for their content, they maintained them for subscribers only. Subscriptions to electronic journals are generally as expensive as the hard copy versions, even though production costs are reduced. Such high costs are a burden for institutions with limited funds, especially those from poor or developing countries. Some publishers allowed open access to contents of back issues of their journals as a compromise and partial response to requests by the scientific community to make scientific information freely available. This trend is expected to continue in the future, thereby expanding the access to scientific data to encompass a wider audience. The current review was immensely facilitated by the availability of online articles, as is the case in general with surveys on the knowledge produced on specific subjects. Efficient dissemination of scientific information is essential for modern society to make informed decisions and establish priorities. 
In relation to question 4 , the studies were classified in reviews, environmental surveys, health effects assessments, technological developments, and integrated studies. Figure 5 shows the number of articles published in 1990-2005. Out of a total of 326 articles, $38 \%$ were surveys on the contamination of environmental compartments, followed by health-related studies (31\%) and reviews (14\%). Only 6\% related to technological improvements (e.g. new analytical methods, new procedures or equipment to reduce contamination, etc.). Less than $10 \%$ of the research projects used an integrated approach (i.e. assessment of environmental contamination and its consequences for human health).

Literature review articles on a specific topic have an irregular cyclical pattern, since they depend on the continuous accumulation of knowledge on the topic and original data published during a period of time. They are only justifiable when enough new data have been obtained that a consolidation of all information becomes necessary. We thus observe peaks in this kind of publication in 1994, 1997, and the highest in 2001 (9 articles). After 2001, we observe a downward trend that will probably be reversed in the near future with a new cycle of reviews such as the present overview.
According to our data, few researchers dedicated efforts to developing new technologies. Publications on new technologies showed a discontinuous pattern over the period surveyed, with a maximum of 5 papers published per year. This could be explained by a persistent attitude in Third World countries, which usually import technologies, including equipment and analytical procedures. Technological development usually takes longer to become available and requires special incentives and conditions. This type of publication involved mostly new or alternative analytical methods such as Yallouz \& Campos 58. Early abatement technologies had little or no impact on the mining process. However, this attitude has been changing in more recent research projects, which present educational components and stronger participation by local communities 59,60 .

Environmental studies were the first to be conducted and detected the widespread mercury contamination in the Amazonian ecosystem; they continued as the main scientific approach throughout the period covered by this review. There was a steady increase in the number of these studies until 2000 (16), after which they leveled off; many of these assessments were done in the context of active or inactive gold-

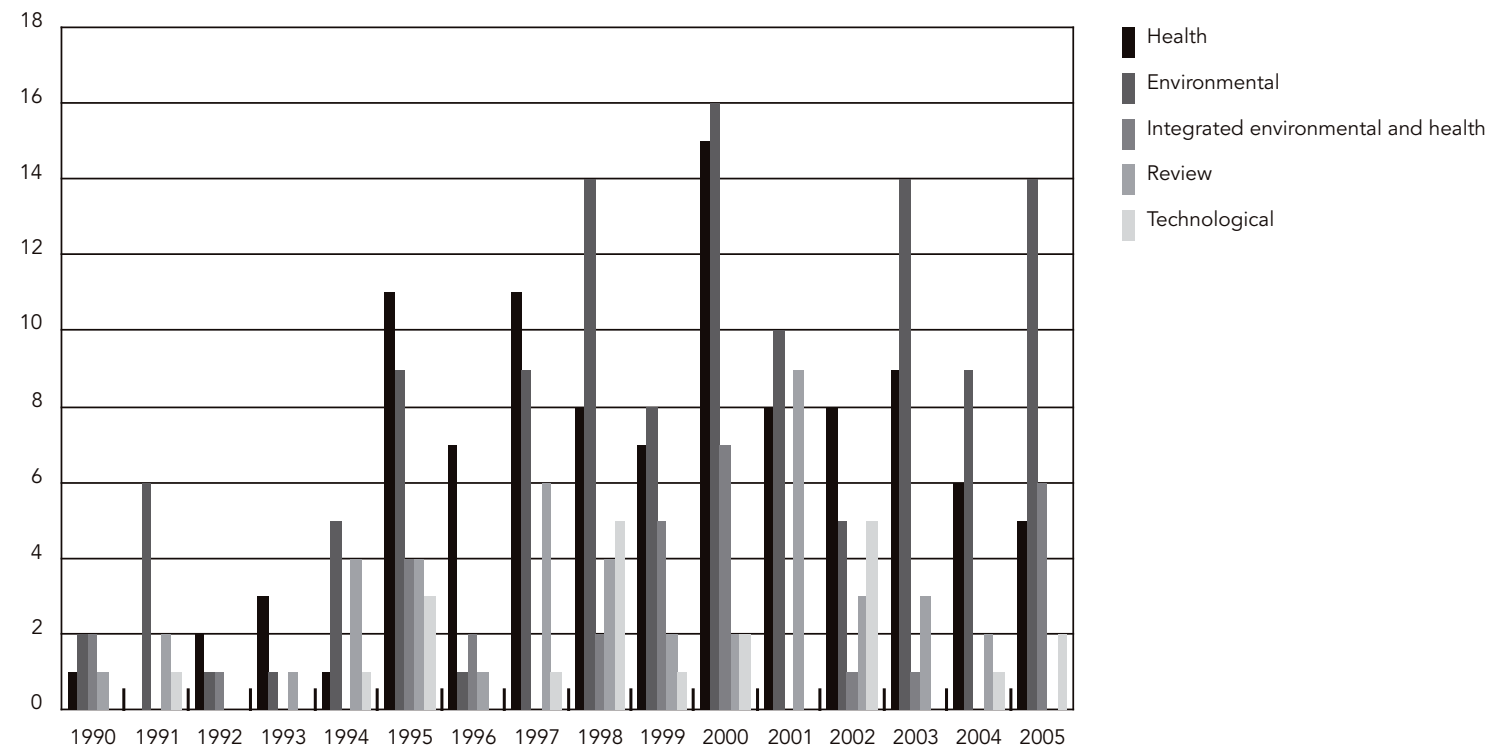


mining areas. Although many articles reported analyses of several environmental matrices simultaneously 61,62,63,64,65,66, these studies analyzed mostly Amazonian fish (39\%), water (16\%), sediments (15\%), and soil (14\%). There were few studies on mercury in air $(9 \%)$, plants $(5 \%)$, or wild animals $(2 \%)$.

The irregular pattern in the geographic location of the studies and the diversity of types of samples analyzed suggest the lack of integrated research plans. Thus, the environmental studies were mostly episodic and isolated in time and space. These unarticulated research efforts produced large amounts of data, but which fail to provide a conclusive picture of mercury contamination in the Amazonian environment and left several knowledge gaps. For example, only three articles on mercury levels in wildlife were identified, although wildlife exposure to methylmercury can occur almost exclusively through fish consumption. Still, there are not enough field data on wildlife mercury concentrations in the Amazon to conclude whether piscivorous wading birds, mammals, and reptiles have suffered adverse effects on a larger scale. The enormous dimensions of the Amazon basin and the absolute lack of basic infrastructure in most of its extension make the need for a well-designed, long-term, and articulated research strategy even more dramatic.

Exclusive assessments of the health effects of mercury contamination on local populations began after the environmental studies. There was an increase from the few studies in the early 1990s to a peak around the year 2000 (15 publications). Health studies only outnumbered environmental studies during brief periods (1995-1997 and 2002). In later years there was a decrease in the number of health-related articles. This might be related at least partially to the increase in the number of studies that simultaneously evaluated environmental mercury contamination and its health effects. Even though the number of integrated studies has been historically small (fewer than seven in any given year), six papers were published using an integrated approach in 2005. The result may indicate that this approach will continue to expand in the future.

Investigating the health impacts of mercury exposure in the Amazon requires a clear understanding of the general conditions in the region. In relation to health studies, the number of publications increased in the Amazon basin countries from the early 1990s until the last years of the period surveyed. From 1990 through 1999, 84 papers were published on the analysis of biological samples, while in the following six years (20002005) this figure reached 65 articles. Mercury exposure was characterized in three ways: (1) through information gathered on occupational history (contact with and use of metallic mercury in gold mining), with these studies now appearing less frequently in the literature; (2) through fish consumption data (frequency and predominant species of fish consumed); and (3) analysis of mercury concentrations in human biological samples, used as an exposure bioindicator. The proper bioindicator is dependent on mercury speciation and exposure route. For individuals chronically exposed to methylmercury via fish consumption, blood or hair samples were analyzed. For those exposed to metallic mercury, as in gold mining, urine samples were used 43,67 . Thus, hair samples were analyzed in $60 \%$ of the health assessments, followed by urine (19\%) and blood (17\%). Other bioindicators analyzed in health studies for specific purposes were breast milk (3\%) and palate cells (1\%).

The number of publications on mercury exposure in Brazilian indigenous populations has increased considerably in recent years. From 1990 through 1998 only five studies were published. However, from 1999 through 2005, 14 articles were published on this issue. These studies showed that native populations living far from gold mining areas had high concentrations of mercury in hair, but no systematic clinical or neurological evaluation was performed 37 . Few studies focused on the clinical and psychological signs of neurological effects of mercury intoxication. In addition, few articles discussed the endemic diseases in the Amazon and their possible role as confounders in the assessment of toxic mercury effects, since the symptoms of mercury exposure and certain infectious diseases can overlap. The health risks of mercury exposure are not monitored by local health services, since health professionals are not trained to distinguish mercury toxicity in the context of the region's endemic diseases 68,69 . This may be one reason why toxic effects of mercury exposure are still not well documented in the Amazonian population. Therefore, there is a need to improve the knowledge on possible synergistic effects between mercury and endemic diseases in the Amazon, which could lead to improvements in the traditional toxicological approach.

The scenario of human mercury exposure in the Amazon has changed, but it is important to understand that the Amazon basin represents a veritable laboratory for studying the effects of low mercury exposure and its interaction with diet, clinical history, and susceptibility to endemic diseases 70. Unfortunately, the current review showed that studies on health effects are still a weak point in terms of knowledge and advances 
relating to mercury exposure in human populations in the Amazon. The review also revealed the lack of research and publications on risk evaluation concerning mercury communication in the Amazon.

This survey indicated improvement in the analytical capabilities of laboratories and personnel training. Several laboratories in Brazil can now perform total mercury measurements in environmental and biological matrices, while few are able to measure methylmercury. Brazilian laboratories participate in inter-laboratory exercises for total mercury determination and the production of certified mercury samples. Integration of research groups from the different Brazilian regions was crucially important to disseminate such analytical capability.

\section{Conclusions}

Mercury contamination in the Amazon region was first brought to light in the late 1980s, when studies underlined the role of the gold rush as a source of mercury in this ecosystem.

Databases from official agencies and public institutions were central to this work. Open access to electronic databases should be encouraged and supported. Sharing data in an open source database can help researchers conduct faster and more comprehensive studies in the future. The efficient dissemination of scientific information is essential for modern society to make informed decisions and establish priorities. However, electronic databases are only as good as the information they contain, and inconsistencies are always possible. Therefore, secondary data analysis and interpretation must be performed with caution.

There was a general increase in the total number of publications during the period surveyed. This trend probably reflects the increase in the number of research groups in many Amazon basin countries working with this issue. The emergence and consolidation of these research groups in several Amazon basin countries resulted directly from Brazilian and international cooperation. Among the Amazonian countries, Brazil had the most international cooperation and the most research institutions working with mercury contamination. The increase in the number of research groups from institutions with headquarters in the Amazon region itself was noteworthy, and these institutions became the majority of the Brazilian research groups working with mercury after 2000.

The spatial pattern of mercury contamination studies in the Amazon basin showed a clustered distribution. In the early 1990s, most studies focused on gold mining along major rivers. Thus, the resulting mercury sources and cycling figures were probably overestimated. More recently, research sites became more scattered in the Amazon Basin, including non-impacted areas. This is probably an outcome of the newer hypothesis about mercury sources in the Amazon, suggesting naturally enriched soils as an important source of mercury. Most studies lack spatial references for the sampling sites, making it difficult to compare data from different studies.

Among the different types of studies on mercury contamination in the Amazon, assessment of environmental compartment contamination was the most common type. Mercury exposure health assessments of local populations were the second most common type of study. However, these studies are still insufficient in terms of knowledge and methodological sophistication. The relationship between human health and environmental contamination is very complex. The human health risks are associated with a variety of economic and social aspects and need to be evaluated within the local context.

There was an increase in studies with an interdisciplinary approach, reflecting the composition of research groups and increased cooperation between institutions from different scientific areas. However, most studies are still temporally and spatially isolated surveys concerned with a specific aspect of mercury contamination in the Amazon. Although these unarticulated research efforts produced large amounts of data, they have proven incapable of providing a conclusive picture of mercury contamination in the Amazonian environment and have left several issues unresolved.

The complexity of the Amazonian ecosystem and the limited knowledge of mercury's biogeochemical cycle in tropical rain forests explain the difficulties faced by the scientific community in assessing the impact of mercury contamination. Thus, current knowledge on the transport, transformation, and fate of mercury in the aquatic and terrestrial environment of the Amazon system is still very superficial. These issues affect the potential for exposure of the local populations and consequently the risk involved.

This overview has shown that there is still no conclusive explanation for the high levels of mercury in some areas of the Amazon basin. Longterm interdisciplinary research is necessary, taking into account the transport, transformation, and fate of mercury and the rapid transformation of forested into cultivated areas. In addition, mercury affects the health of local populations and must be studied with an integrated and participatory approach, including an environmental education program. 


\section{Resumo}

Esta pesquisa apresenta uma visão geral dos estudos desenvolvidos sobre a contaminação por mercúrio na bacia Amazônica e a evolução destes estudos no período 1990-2005. O estudo baseou-se em extensiva e sistemática revisão utilizando bases de dados bibliográficas disponíveis na Internet e em uma revisão dos projetos de pesquisa realizados por grupos de pesquisa. Além disso, os grupos de pesquisa brasileiros foram identificados pela base de dados do Conselho Nacional de Desenvolvimento Científico e Tecnológico (CNPq). Um sistema de informação geográfica foi usado para localizar os estudos conduzidos. Diferentes aspectos da contaminação por mercúrio na Amazônia foram analisados (estudos ambientais, impactos na saúde humana, melhorias tecnológicas). No período de 1990-2005, foram identificadas 455 publicações. As principais realizações e as lacunas existentes em relação aos estudos ambientais e de saúde humana foram identificadas e discutidas. Apesar de variações, há um aumento geral do número total de publicações por ano desde o começo da década de 1990 (menos de 20) para o final do período estudado (mais de 30), expresso por meio dos artigos publicados em revistas indexadas.

Intoxicação por Mercúrio; Poluição Ambiental; Mercúrio; Ecossistema Amazônico

\section{Contributors}

S. Hacon and P. R. G. Barrocas contributed to the analysis of the bibliographical references and the data obtained from the Internet database search, structuring and drafting of the article, and discussions for preparing the article. A. C. S. Vasconcellos collaborated in the literature survey by conducting Internet database searches, constructing the database, and preparing the graphs in the article. C. Barcellos contributed to the georeferencing of the study sites and spatial distribution analysis J. C. Wasserman collaborated in the review and selection of the publications obtained through the database search, data analysis, and review of the article. R. C. Campos participated in the discussion of the article's structure and review. C. Ribeiro and F. B. Azevedo-Carloni contributed to the literature search and construction of the database.

\section{References}

1. Lacerda LD, Pfeiffer WC, Ott AT, Silveira EG. Mercury contamination in the Madeira River, Amazon $\mathrm{Hg}$ inputs to the environment. Biotropica 1989; 21:91-3.

2. Martinelli LA, Ferreira JR, Forsberg BR, Victoria RL. Mercury contamination in the Amazon - a gold rush consequence. Ambio 1988; 17:252-4.

3. Pfeiffer WC, Lacerda LD. Mercury inputs into the Amazon Region, Brazil. Environmental Technology Letters 1988; 9:325-30.

4. Malm O, Pfeiffer WC, Souza CMM, Reuther R. Mercury pollution due to gold mining in the Madeira River Basin, Brazil. Ambio 1990; 19:11-5.

5. Aula I, Braunschweiler H, Malin I. The watershed flux of mercury examined with indicators in the Tucurui reservoir in Para, Brazil. Sci Total Environ 1995; 175:97-107.

6. Akagi H. Mercury pollution in the Amazon, Brazil. Japanese Journal of Toxicology and Environmental Health 1995; 41:107-15.
7. Richard S, Arnoux A, Cerdan P, Reynouard C, Horeau V. Mercury levels of soils, sediments and fish in French Guiana, South America. Water Air Soil Pollut 2000; 124:221-44.

8. Lacerda LD, Solomons W. Mercúrio na Amazônia: uma bomba relógio química? Rio de Janeiro: Centro de Tecnologia Mineral; 1992.

9. Pfeiffer WC, De Lacerda LD, Malm O, Souza CMM, Da Silveira EG, Bastos WR. Mercury concentrations in inland waters of gold-mining areas in Rondônia, Brazil. Sci Total Environ 1989; 87-88:223-40.

10. Jensen S, Jernelov A. Biological methylation of mercury in aquatic organisms. Nature 1969; 223:753-4.

11. Ebinghaus R, Hintelmann H, Wilken RD. Mercurycycling in surface waters and in the atmosphere: species analysis for the investigation of transformation and transport properties of mercury. Fresenius J Anal Chem 1994; 350:21-9. 
12. Morel FMM, Krapiel AM, Amyot M. The chemical cycle and bioaccumulation of mercury. Annu Rev Ecol Syst 1998; 29:543-66.

13. Barkay T, Miller MS, Summers AO. Bacterial mercury resistance from atoms to ecosystems. FEMS Microbiol Rev 2003; 27:355-84.

14. Dorea JG, Barbosa AC, Ferrari I, Souza JR. Mercury in hair and in fish consumed by riparian women of the Rio Negro, Amazon, Brazil. Int J Environ Health Res 2003; 13:239-48.

15. Dorea JG, Barbosa AC. Fruits, fish and mercury: further considerations. Environ Res 2004; 96:102-3.

16. Barbosa AC, Souza J, Dórea JG, Jardim WF, Fadini PS. Mercury biomagnification in a tropical black water, Rio Negro, Brazil. Arch Environ Contam Toxicol 2003; 45:235-46.

17. Fadini PS, Jardim WF. Is the Negro River Basin (Amazon) impacted by naturally occurring mercury? Sci Total Environ 2001; 275:71-82.

18. Lechler PJ, Miller JR, Lacerda LD, Vinson D, Bonzongo JC, Lyons WB, et al. Elevated mercury concentrations in soils, sediments, water, and fish of the Madeira River basin, Brazilian Amazon: a function of natural enrichments? Sci Total Environ 2000; 260:87-96.

19. Niagru JO. Mercury pollution in Brazil. Nature 1992; 356:389.

20. Hylander LD, Silva EC, Oliveira LJ, Silva S, Kuntze EK, Silva DX. Mercury levels in Alto-Pantanal: a screening study. Ambio 1994; 23:478-84.

21. Villas Bôas RC. The mercury problem in the Amazon due to gold extraction. Journal of Geochemical Exploration 1997; 58:217-22.

22. Wasserman JC, Hacon S, Wasserman MA. Biogeochemistry of mercury in the Amazonian environment. Ambio 2003; 32:336-42.

23. Akagi H, Naganuma A. Human exposure to mercury and the accumulation of methylmercury that is associated with gold mining in the Amazon Basin, Brazil. J Health Sci 2000; 46:323-8.

24. Roulet M, Lucotte M. Geochemistry of mercury in pristine and flooded ferralitic soils of a tropical rain forest in French Guiana, South America. Water Air Soil Pollut 1995; 80:1079-108.

25. Roulet M, Lucotte M, Rheault I, Tran S, Farella N, Canuel R, et al. Mercury in Amazonian soils: accumulation and release. In: Proceedings of IV International Conference on the Geochemistry of the Earth's Surface. Leeds: University of Leeds; 1996. p. 453-7.

26. Roulet M, Lucotte M, Mergler D, Guimarães JRD. The geochemistry of mercury in the central Amazonian soils developed on the Alter do Chao formation of the lower Tapajos River Valley, Para State, Brazil. Sci Total Environ 1998; 223:1-24.

27. Veiga MM, Meech JA, Onate N. Mercury pollution from deforestation. Nature 1994; 368:816-7.

28. Lacerda LD. Amazon mercury emissions. Nature 1995; 374:20-1.

29. Hacon S, Artaxo P, Gerab F, Yamasoe MA, Campos $\mathrm{RC}$, Conti LF, et al. Atmospheric mercury and trace elements in the region of Alta Floresta in the Amazon basin. Water Air Soil Pollut 1995; 80:273-83.
30. Artaxo P, Campos RC, Fernandes ET, Martins JV, Xiao ZF, Lindqvist O, et al. Large-scale mercury and trace element measurements in the Amazon Basin. Atmos Environ 2000; 34:4085-96.

31. Fearnside PM. Deforestation control in Mato Grosso: a new model for slowing the loss of Brazil's Amazon Forest. Ambio 2003; 32:343-5.

32. Aula I, Braunschweiler H, Leino T, Malin I, Porvari P, Hatanaka T, et al. Levels of mercury in the Tucuruí Reservoir and its surrounding area in Para, Brasil In:Watras CJ, Huckabee JW, editors. Mercury pollution: integration and synthesis. Boca Raton: Lewis Publishers; 1994. p. 21-40.

33. Leino $\mathrm{T}$, Lodenius M. Human hair mercury levels in the Tucurui area, state of Para, Brazil. Sci Total Environ 1995; 175:119-25.

34. Kehrig HA, Malm O, Akagi H. Methylmercury in hair samples from different riverine groups, Amazon, Brazil. Water Air Soil Pollut 1997; 97:17-29.

35. Barbosa AC, Garcia AM, Souza JR. Mercury contamination in hair of riverine populations of Apiacas Reserve in the Brazilian Amazon. Water Air Soil Pollut 1997; 97:1-8.

36. Vasconcellos MBA, Saiki M, Paletti G, Pinheiro RMM, Baruzzi RG, Spindel R. Determination of mercury in the head hair of Brazilian population groups by neutron-activation analysis. Journal of Radioanalytical and Nuclear Chemistry 1994; 179:369-74.

37. Vasconcellos MBA, Bode P, Paletti G, Catharino MGM, Ammerlaan AK, Saiki M, et al. Determination of mercury and selenium in hair samples of Brazilian Indian populations living in the Amazonic region by NAA. Journal of Radioanalytical and Nuclear Chemistry 2000; 244:81-5.

38. Santos ECD, Jesus IM, Camara V, Brabo E, Loureiro ECB, Mascarenhas A, et al. Mercury exposure in Munduruku Indians from the community of Sai Cinza, State of Para, Brazil. Environ Res 2002; 90:98-103.

39. Santos ECO, Camara VM, Jesus IM, Brabo ES, Loureiro ECB, Mascarenhas AFS, et al. A contribution to the establishment of reference values for total mercury levels in hair and fish in Amazonia. Environ Res 2002; 90:6-11.

40. Crompton P, Ventura AM, Souza JM, Santos E, Strickland GT, Silbergeld E, et al. Assessment of mercury exposure and malaria in a Brazilian Amazon riverine community. Environ Res 2002; 90:69-75

41. Barbosa AC, Boischio AA, East GA, Ferrari I, Gonçalves A, Silva PRM, et al. Mercury contamination in the Brazilian Amazon. Environmental and occupational aspects. Water Air Soil Pollut 1995; 80:109-21.

42. Dorea JG, Souza JR, Rodrigues P, Ferrari I, Barbosa AC. Hair mercury (signature of fish consumption) and cardiovascular risk in Munduruku and Kayabi Indians of Amazonia. Environ Res 2005; 97:209-19.

43. National Research Council. Toxicological effects of methylmercury. Washington DC: National Academies Press; 2000. 
44. Myers GJ, Davidson PW, Shamlaye C. A review of $\mathrm{MeHg}$ and child development. Neurotoxicology 1998; 19:313-28.

45. Mergler D. Review of neurobehavioral deficits and river fish consumption from the Tapajós (Brazil) and St. Lawrence (Canada). Environ Toxicol Pharmacol 2002; 12:93-9.

46. World Health Organization/International Program in Chemical Safety. Environmental health criteria 101 methyl mercury. Geneva: World Health Organization; 1990.

47. Grandjean P, White RF, Nielsen A. MeHg neurotoxicity in Amazonian children downstream from gold mining. Environ Health Perspect 1999; 107:587-91.

48. United Nations Environment Program. Chemicals. Global mercury assessment. Geneva: United Nations Environmental Program; 2002.

49. Lebel J, Mergler D, Branches F, Lucotte M, Amorim M, Larribe F, et al. Neurotoxic effects of low-level MeHg contamination in the Amazonian basin. Environ Res 1998; 79:20-32.

50. Guimarães R, Lourenço R, Cosac S. A pesquisa em epidemiologia no Brasil. Rev Saúde Pública 2001; 35:321-40.

51. Villas-Bôas RC, Beinhoff C, Silva RC, editors. Mercury in the Tapajós basin. Rio de Janeiro: Centro de Tecnologia de Minerais; 2001.

52. Hacon S, Rochedo ER, Campos R, Rosales G, Lacerda LD. Risk assessment of mercury in Alta Floresta, Amazon Basin-Brazil. Water Air Soil Pollut 1997; 97:91-105.

53. Harada M, Nakanishi J, Yasoda E, Pinheiro MDN, Oikawa T, Guimaraes GD, et al. Mercury pollution in the Tapajós river basin, Amazon. Mercury level of head hair and health effects. Environ Int 2001; 27:285-90.

54. Jesus I, Santos ECD, Brabo ED, Loureiro ECB, Camara VD, Mascarenhas AFS, et al. Exposure to elemental mercury in urban workers and gold miners from the Tapajós region, Para, Brazil. Bull Environ Contam Toxicol 2001; 67:317-23.

55. Guimaraes JRD, Meili M, Hylander LD, Silva EDE, Roulet M, Mauro JBN, et al. Mercury net methylation in five tropical flood plain regions of Brazil: high in the root zone of floating macrophyte mats but low in surface sediments and flooded soils. Sci Total Environ 2000; 261:99-107.

56. Maurice Bourgoin L, Quiroga JL, Guyot JL, Malm O. Mercury pollution in the upper Beni River, Amazonian Basin: Bolivia. Ambio 1999; 28:302-6.

57. Santos GM, Cordeiro R, Silva EV, Turcq B, Lacerda LD, Fifield LK, et al. Chronology of the atmospheric mercury in Lagoa da Pata basin, Upper Rio Negro region of Brazilian Amazon. Radiocarbon 2001; 43:801-8.
58. Yallouz AV, Campos RC, Paciornik S. A low-cost non-instrumental method for semiquantitative determination of mercury in fish. Fresenius J Anal Chem 2000; 366:461-5.

59. Caruso Project. Mercury exposure and ecosystem health in the Amazon. http://www.unites.uqam.ca/ gmf/caruso/caruso_home.htm (accessed on 03/ Mar/2006).

60. Hacon SS, Farias RA, Campos RC, Argento RR, Rossi AP, Caires SM, et al. Current scenarios of human exposure to mercury in the northern region of Mato Grosso, Amazon Basin. Environ Sci 2003; 10:121-34.

61. Wasserman JC, Queiroz EL. The attenuation of concentrations model: a new method for assessing mercury mobility in sediments. Quim Nova 2004; 27:17-21.

62. Almeida MD, Lacerda LD, Bastos WR, Herrmann JC. Mercury loss from soils following conversion from forest to pasture in Rondonia, Western Amazon, Brazil. Environ Pollut 2005; 137:179-86.

63. Brabo ES, Angelica RS, Silva AP, Faial KRF, Mascarenhas, Santos ECO, et al. Assessment of mercury levels in soils, waters, bottom sediments and fishes of Acre state in Brazilian Amazon. Water Air Soil Pollut 2003; 147:61-77.

64. Herpin U, Cerri CC, Carvalho MCS, Market B, Enzweiler J, Friese K, et al. Biogeochemical dynamics following land use change from forest to pasture in a humid tropical area (Rondonia, Brazil): a multi-element approach by means of XRF-spectroscopy. Sci Total Environ 2002; 286:97-109.

65. Cordeiro RC, Turcq B, Ribeiro MG, Lacerda LD, Capitaneo J, Silva AO, et al. Forest fire indicators and mercury deposition in an intense land use change region in the Brazilian Amazon (Alta Floresta, MT). Sci Total Environ 2002; 293:247-56.

66. Roulet M, Lucotte M, Guimarães JRD, Rheault I. Methylmercury in water, seston, and epiphyton of an Amazonian river and its floodplain, Tapajos River, Brazil. Sci Total Environ 2000; 261:43-59.

67. Friberg L, Nordberg G, Vouk V, editors. Handbook on the toxicology of metals. v. II. New York: Elsevier; 1986.

68. Santos EO. Garimpagem e saúde. In: Mathis A, Rehaag R, organizadores. Conseqüências da garimpagem no âmbito social e ambiental da Amazônia. Belém: Editora Cepuj; 1993. p. 36-72.

69. Santos EO, Loureiro ECB, Jesus I, Brabo ES, Silva RSU, Soares MCP, et al. Diagnóstico das condições de saúde de uma comunidade garimpeira na região do Tapajos, Itaituba, Pará-Brasil. Cad Saúde Pública 1992; 11:212-25.

70. Silbergeld E, Nyland J. Mercury exposures and autoimmune disease. Toxicol Appl Pharmacol 2004; 197:147.

Submitted on 23/Aug/2006

Final version resubmitted on 28/Jun/2007

Approved on 03/Jul/2007 